\title{
Space Construction in Media Reporting A Study of the Migrant Space in the 'Jungles' of Calais
}

\author{
Yasmin Ibrahim, Anita Howarth
}

\section{Introduction}

In September 2009, French riot police armed with flame-throwers, bulldozers and chain saws demolished an illegal migrant camp in Calais known locally as "the Jungle" and dispersed its occupants (Garnham 2009). Over two years the camp had grown from a handful of occupants in a few makeshift tents to over 800 in a sprawling shantytown spilling into the town of Calais (Rawstorne 2009). This article explores how British newspapers' use of the "jungle" metaphor constructed a particular social imaginary of migrant spaces and their informal camps at a time when migrant shelters were a focus of policy and public concern. The jungle metaphor signified a barbaric space characterised by environmental degradation and lawlessness that encroached on ordered spaces of white civility. This construct was used to justify the razing of the camp, the demolition of the shelters and the dispersing of its occupants by the French police. However, mini-camps sprung up almost immediately all along the French coastline (Allen 2009c) and newspapers expressed fears of the local community that these could grow into mini-jungles (Allen 2009 b) - a fear realised a year later with the emergence and demolition of the "new jungle" in a small village near Dunkirk (Finan and Allen 2010) which was similarly demolished.

Benedict Anderson (1991) argues that the notion of "nation-ness" has become a central construct in many aspects of modern thought. He posits the concept of a nation as an imagined community, as members "will never know most of their fellow members" and the notion of citizenship and belonging to the nation enables people to imagine the boundaries of a nation even when these boundaries may not physically exist $(1991,6)$. One of the significant historical developments, which facilitated the emergence of national consciousness, is the rise of print capitalism. Newspapers as part of this print capitalism facilitated this imagination and communion with the unknown other. A prominent aspect of Anderson's imagined community is the role of media, particularly print media where these can facilitate national conversations. These conversations allow people to be aware of each other's existence, experience and belonging to a community. Media are intrinsically implicated in creating a national consciousness and a bond between individuals. According to Anderson, "these fellow-readers to whom they were connected through print, formed the embryo of the nationally imagined community" $(1991,44)$. Thus, the role of newspapers as cartographers of the imagined community is facilitated through its sustained discourses and is an important part of the discursive, metaphorical and visual construction of the nation state in our everyday lives. This imagination of "us" is crafted by inserting imagined boundaries, defining inclusion and by marking out the "Other". In other words, media as a cultural artefact has a cartographic function in people's everyday lives, infusing spatial geography and boundaries and enacting these through narratives, visual and discursive frames. Despite the eminence of Anderson's thesis "imagined communities", this cartographic role of the media, particularly print media and its incumbent journalistic techniques to sustain a social imaginary of an imagined community, is under explored in journalism studies. What is well conceived in media and communication studies as well as broader scholarship on information and communications technologies (ICTs) is the ability of media to transcend time and space and to reconfigure 
temporal and proximity-distance frames (Scannell 1989; Moores 2004; Ibrahim 2012).

This paper acknowledges the role of media and particularly newspapers in constantly invoking an imagined spatial geography in its discussions of national interest. The cartographic role of media is accomplished through a multitude of journalistic techniques including the use of images, imagery, narratives, metaphors, distance framing and robust agenda setting, where notions of belonging to a defined discursive space can elicit both cerebral and visceral responses. As Durkheim observes in the Elementary Forms of the Religious Life (1915), time and space are social constructs. Places and spaces as social constructs are often subjected to ideological struggles over meaning. The sheer act of identification, the assignment of a place in a social structure, indicates distinctive roles, capacities for action and access to power within the social order (Harvey 1990, 419). David Harvey's (1990) materialist construction of space as a product of social relations and ideological struggles imbues a Marxist perspective to space production, equally implicating media as a capitalist and ideological enterprise within this frame. Hence media's production of space in sustaining the social imaginary of the nation-state is not divorced from the political context, power or ideological struggles. As Harvey $(1990,419)$ observes, "the very act of naming geographical entities implies a power over them, most particularly the way in which places, inhabitants and social functions are represented".

The framing of space in media while renewing the social imaginary of an imagined community is political. It is within this premise we analyse the spatial metaphor of the jungle in Calais. Our analysis of the spatial metaphor of the jungle draws on the concept of spatialisation as a social imaginary (Shields 1999), that emerges out of a politics of territoriality centred on discursive and material practices of media. Beyond Anderson's "imagined community," the discursive media practices which gave rise to jungle discourses need to be understood within a particular context of terrestrial politics where the unbounded regional entity of the European Union is juxtaposed against the bounded notion of the nation-state (whether it be the UK or France). The EU is presented as non-coterminous, where the borders are porous and malleable. The EU, and in particular France, is perceived as a space where large numbers of illegal migrants congregate at or near the French ports within the context of a de facto French policy of closing, banning or demolishing migrant shelters between 2002 and 2011. Against this political context, we argue that distinct spatialisation techniques were employed by newspapers to construct the violation of a bounded space in the discourses of the jungle. The habitus of space by the other was tightly entwined with discourses of White morality versus territorial violation. In so doing it reinforced and legitimised a particular geopolitics of space, while illuminating the cartographic role of newspapers in renewing the social imaginary of an imagined community.

\section{| Spatialization and Social Imaginaries}

Spaces can be socially, materially and discursively constructed (Harvey 1973; Massey 1991; May 1996; Shields 1999). Shields conceptualizes this spatialization as a "social imaginary," where spatial divisions and distinctions provide the means to ground hegemonic ideologies and social practices (1999). In these "social imaginaries," issues of belonging, boundaries and othering can reflect discursive and material practices of "us" and "them", exclusion and inclusion. More recent literature has developed this further, arguing that landscapes and dominant features in these "become spatially bounded scenes that visually communicate what belongs and what does not" (Trudeau 2006, 421). They thus become critical to the construction of a "territorialized politics of belonging" in which the discourses and practices that maintain boundaries "correspond to the imagined geographies of a polity and to the spaces that normatively embody the polity" (Trudeau 2006, 421).

How the media construct boundaries with regard to migration needs to be understood within wider shifts in policy discourses of migrants and migration. Since the 1980s, assumptions and discourses about the rights of refugees to protection have been eroded as governments struggled to deal with increases in unregulated mass migration, people trafficking and international terrorism (Geddes 2004; Bosworth 2012). States, rather than offering sanctuary, have reframed migration as involving "risky outsiders and threatened insiders" and refugees as migrants (Millner 2011). A security-judicial apparatus has grown up around tighter border controls aimed at keeping migrants out and criminalising "certain forms of movement ... [so] effectively rendering large proportions of the world's population as illegal" (Aas 2011, 26). "New spaces" have emerged both to detain migrants during the asylum process and as informal camps of makeshift shelters erected by migrants on wasteland or in disused industrial buildings in towns and cities (Isin, Engin and Rygiel 2007, 171). The security-judicial border controls render these as spaces of exception where the usual rights and protections afforded refugees or citizens are denied to those suspected of being 
illegal migrants. These include the right not to be detained as well as the right to shelter and to welfare benefits (Isin, Engin and Rygiel 2007; Aas 2011).

\section{| EU Politics of Territoriality and The Social Imaginary of The Jungle}

The politics of territoriality has taken a particular form with "Fortress Europe," a term that conveys the sense of a space under siege from waves of irregular migration, the response to which has been the tightening of the securityjudicial apparatus on the EU's external borders (Bosworth and Guild 2008, 213). Recent legal changes require migrants to apply for asylum at the point of entry, but most wait until they reach their preferred destination - often Germany and the UK - so as many as 90\% may be illegal under the new laws (Oxfam cited in Millner 2011, 236). The EU has also relaxed internal borders under the Schengen Agreement, which allows free, undocumented travel between signatory countries. Britain opted out of the Agreement and retained border controls, the consequence of which has been to render the French coastline the "extreme periphery" of the Schengen area and a site of relatively large congregations of migrants seeking to cross the sea border (Thomas 2013). Calais has seen a particular concentration of migrants because of its multi-modal transport links (i.e. ferry, train and lorry) which offer more opportunities for stowaways. As such, this renders Calais as a key site of cross-border tension as well as co-operation between the two countries.

French politicians blame the "problem" of large numbers of migrants in Calais on what they see as a clash between the attraction of Britain's over-generous benefit system and "inhumane" border controls, which block movement across the Channel, thus creating a bottleneck on their side of the border (Howarth and Ibrahim 2012). Conversely, British politicians blame France for loose border controls, summed up in expressions such as "we don't have a barrier, we have a sieve" (Damien Green cited Bosworth and Guild 2008, 704). Both governments have responded by seeking to deter migrants with more surveillance and tighter border controls in Calais (Mulvey 2010) and a raft of new laws, but rather than solve the problem it has created the sense of a "system ... in perpetual crisis"; both governments "lost control of the debate" and British media hostility towards migrants hardened (Mulvey 2010, 456).

It is within this context of crisis that the jungle metaphor was applied by newspapers to the migrant camps on the French coastline. Rygiel has argued that Europe's migrant camps are "sites of contestation"” so their "very meaning" needs to be explored $(2011,1)$. At one level, the meaning of camps studied in this article is functional: they are located near major transit areas which present migrants with opportunities to leap onto passing vehicles headed across the Channel and meet the basic need for shelter. However the camps are also visible symbols of the presence of migrants, the scale of migration, and hence failed migration policies (Boswell 2012; Ibrahim 2011; Howarth and Ibrahim 2012). These two elements converged in the row over Sangatte Red Cross Centre, which closed in 2002 after a riot and pressure from the British government who argued that such shelters acted as a magnet for more migrants (Boswell 2012). This marked the beginning of a sustained policy in which charities were allowed to provide food, hot showers and basic medical care but not migrant shelters which were closed, banned or demolished. This fragmented policy forced them to erect their own makeshift shelters. The sprouting of these makeshift camps between 2007 and 2011 saw the emergence of the spatial metaphor of the jungle.

The closure of Sangatte brought British newspaper attention to Calais as a major conduit for cross-channel illegal migration (Boswell 2012). The row over the shelter became a "focusing event," which grounded and concretised the more elusive problem of illegal migration for journalists (Boswell 2012). It also gave impetus to a decade-long campaign by British newspapers, particularly in the two mid-market titles, the Daily Mail and Express, on illegal migration (see Ibrahim 2011; Howarth and Ibrahim 2012). Editors have argued that their campaigns were in the interest of their readers because the scale of migration posed major demographic changes and because of the failure of the government to solve the problem. However human rights organisations and analysts counter that coverage has drawn on "de-humanizing" labels for migrants and created a "misleading picture" of immigration "fuel[ing] political prejudice ... and extremism” in Britain (Commission for Racial Equality 2007, 98; Migration Observatory 2013).

These political and social contexts have shaped the conditions in which a particular social imaginary of the jungle in British newspaper discourses emerged between 2007 and 2010. The spatial-political dimension created a sense of space under threat, in crisis, and the corresponding response of governments as being inadequate. At the same time there was a politicization of and increased media attention on migrant shelters and the spaces where 
these sprung up. The spatial metaphor of the jungle is highly malleable, offering multiple cultural meanings (see Dove 1992); ranging from the exotic backdrop in wildlife documentaries (Horak 2006), the staged set and "contrived construction" of reality television (Wright 2006), to the older colonial meanings of the jungle as a barbaric space found in Rudyard Kipling's Jungle Book (1894) and Joseph Conrad's Heart of Darkness (1899).[1] What Kipling, Conrad - and more recently, the British newspapers analysed below - draw on is the literal meaning of the AngloIndian word "jungle" as "tangled thickets" (Zimmerman 1987, vii, cited in Dove 1992) and the dialectic between environmental characteristics of "feral" plants and animals and the culture of human inhabitants who do not "obey the norms and laws of the country" (Dove 199, 239).

For colonialists surveying the foreign land, this dialectic took on an added meaning in which the jungle was "an absence of civilization," (Dove 1992, 239, 240) and in Kipling's writings a "threat to the maintenance of order and hierarchy" and the "conflict between orderly colonialism and anarchic nativism"(Nyman 2001, 1007). Similarly, in Conrad's work the other is "the antithesis of Europe and civilization" (Achebe 1977, 324), the "savage counterpart to the refined" (Achebe 1977, 324) and a western hierarchy that ultimately "dehumanizes" the African other (Achebe 1977, 326). The "law of the jungle" evoked by the newspapers analysed below is not in the Kipling sense of a space where the rules of a community are intended to ensure order and the protection of individuals and society from threats to these (McBratney 1992), but more in the Conrad sense of a corrosive, corrupting force of the jungle environment where all norms are suspended and the civilised individual is debased. The metaphor of the jungle created a distinct "othering" of migrants as lesser human. Edward Said (1978) in his study of Orientalism observes how outsiders can impose associations and connotations on the identities of people by manipulating or coalescing traits and attributes. The metaphor of the jungle created a spatial category in which to isolate the migrant and demark him or her as different from the civilized population.

\section{| Spatialization Techniques in Newspaper Discourses}

The discursive practices of the newspapers drew on the spatial metaphor of the jungle to construct a particular social imaginary of migrant spaces and shelters and their urgent threat to civilised Europe. The metaphor of the jungle as a spatialization technique was both able to create a distance from the plight of the migrants while inserting its imminent threat in the proximate locale of the French coastline. Discursive practices here also refer to the construction of collective meanings around dominant thematic discourses; the ideological premises and conflicts implicit in these; and the discursive technique - in particular of the spatial metaphor - used to construct spaces and their occupants in terms of belonging and un-belonging, that is, as "them" and "us", exclusion and inclusion. We analysed the use of the jungle metaphor in 121 online articles in Britain's two mid-market newspapers: the Daily Mail and the Express. (This was supplemented with four offline articles published in the Express, which mentioned the jungle in 2007 and 2008 but are not available online.) Both newspapers have campaigned against immigration and been criticised by human rights organizations for their coverage of migrant and asylum issues, and while their choice of discourse might be dramatic, their ideological positioning on immigration is broadly consistent with that of the "quality" newspapers (see Howarth and Ibrahim 2012). Furthermore, major changes in demography rendered the mid-market one of the most politically significant newspaper segments since the 1990s (Greenslade 2004). It is also a market segment dominated by the Daily Mail, which has come to occupy a space of particular political power and in tandem influence on political debate (Davies 2009) including on issues of immigration. The sensitivity of the British government to this can be seen in the way in which immigration issues, in particular cross-Channel illegal migration, have moved up the political and policy agenda (Mulvey 2010).

Beyond deconstructing the metaphor of the jungle, we analysed the newspaper discourses at three distinct levels of spatialization: the functional (shelter); the environmental (internal and external conditions - camps and political conditions); and the barbaric (violent criminality and lawlessness) and struggles against this. The analyses were organised thematically to show spatial and temporal continuities and shifts from the emergence of the Calais Jungle as a space of the unordered and uncouth, in which the growing barbarism serves to legitimise brutal or violent practices (i.e. demolition), to eradicate makeshift camps or shelters, render occupants of the jungle sub-human and those who were deemed criminal who needed to be expelled, or vulnerable so needed to be protected. The demolition of the camps - and the vegetation in them - thus becomes deeply symbolic of the politics of territoriality, manifest in attempts to reclaim civilised space from the jungle; to root out the corrosive and corrupting elements 
that had crept in and threatened ordered, lawful Calais. However the sprouting of "new jungles" became visible manifestations of the failure of these eradication techniques and ultimately, the failure of policies aimed at deterring new migrants, the refusal of the French courts to legitimise detention and the deportation of migrants, the refusal of Britain to open its borders to more migrants, and an influx of refugees from the Arab Spring. Ultimately, what was threatened was more than civilised suburbia; what was threatened was one of the key edifices of the EU - the Schengen Agreement on free movement within the EU.

\section{The Jungle as the Uncouth, Unordered Space}

The metaphor of the Jungle as a barbaric space did not emerge with the first mentions of the term in the British newspapers. Initially, the newspapers referred to a handful of "makeshift" shelters on "inhospitable scrubland" on the main road to the port of Calais, a base from where migrants could leap onto passing vehicles headed across the Channel (Tristem 2007). By 2009, however, its occupants numbered over 800 in flimsy tents in a "sprawling shantytown ... that grows by the day" (Rawstorne 2009), that is, a town within a town characterised by organic, unordered growth. The newspapers saw it as the "latest focus of a long and unending saga" (Rawstorne 2009), a highly visible and semi-permanent "symbol of Europe's struggle with illegal migration" (Express 2009). In view of this, the jungle metaphor became a symbol of failed policies by creating a social imaginary of a barbaric space.

The jungle metaphor operated at two levels. Barbarism as environmental degradation was evident in discourses of "squalor" (Sparks 2009a) and an assault on the senses where the "smell of human excrement and acrid smoke was almost overwhelming" (Reid 2009). Living conditions in the camp were likened to the "trenches" of World War I (Bracchi 2009) and labelling these "inhumane" was seen as an "understatement ... of the filthy conditions" in which "migrants have to survive in their tents, in the mud, with minimum hygiene" (Allen 2009c). However, rather than focusing on the inhabitable conditions in the camps, the jungle discourse sought to alienate the public.

The camps were presented as unordered and unlawful spaces through the jungle metaphor. The Jungle was seen as a "magnet" and a "hiding place" for rapists, gang masters and people traffickers; a "no go area for the police" (Allen 2008). The journeys to Calais from Afghanistan, North Africa and the Middle East, while long and hard were seen as "civilised compared with ... the Jungle,"(Fernandes 2009) for this was a space where the "law of the jungle" reigned (Rawstorne 2009). This was savage "law" of murder, rape, and fights between rival ethnic gangs armed with "clubs, metal bars and knives," all desperate to be one of the "few who ...can get past the security checks" to get on one of the lorries headed for Britain (Allen 2009a). It was also a space of desperation coupled with an illegal economy of monetising human trafficking, where migrants idealised Britain as an "Eldorado" (Reynolds 2009) and were willing to "stop at nothing"(Sparks 2009c). The law of this Jungle took on a particular form with unscrupulous "criminal gangs exporting illegal migrants to Britain" who were free to operate largely unchecked (Allen 2009c). It was a space of "big business" infiltrated by "organised crime," and where people traffickers could charge the migrants up to $\$ 20,000$ to get to Britain (Fernandes 2009).

The spatial references were recurrent in the newspaper discourses, highlighting how the disorder was often violating the ordered spaces of the civilised. Fights between migrants escalated into inter-ethnic "turf wars" which created "months of violence and disorder" on the streets of Calais (Hickley 2009). In one incident about 70 migrants "armed with iron bars and knives" started fighting with each other on one of the main streets (Bracchi 2009). The loss of control over one's environment became evident in the immediacy where the "situation is deteriorating fast" (Rawstorne 2009) and the violence "becoming more indiscriminate" with sexual assaults on a pregnant woman and attacks on British holidaymakers (Bracchi 2009). Recreational spaces became "no go area[s]" (Rawstorne 2009) and businesses were disrupted, as was daily life; a "caravan showroom ... [was] now boarded up", the owner of a truckers" café "at his wits end" was considering doing likewise (Bracchi 2009), and local traders had "seen business plummet as truckers fearful of stopping lest immigrants board their lorries, boycott the area" (Rawstorne 2009). The "law of the jungle", newspapers claimed, had extended "beyond the boundaries of this god-forsaken "community," disrupting local business and threatening local residents with their desperation and determination to reach Britain (see Bracchi 2009).

What emerged between 2007 and 2009 in these discourses was the jungle as a barbaric space of environmental degradation and a space overrun by the uncouth and unordered, which warranted a robust response from the forces of law and order. 


\section{Eradicating the Jungle}

The newspaper discourses on these migrant camps agitated for responses from the French authorities. The response demanded by the British newspapers from the French authorities was slow to come. Local residents talked about "setting up vigilante groups to forcibly clear migrants" (Rawstorne 2009) and an arson attack on a prefabricated unit intended to house hot showers was attributed to local residents "angry at the presence of migrants" (Allen 2009c). French minister Eric Besson pledged that the "the law of the jungle will reign no longer" and that the "base camp for human traffickers" (Bracchi 2009) would be demolished, to which his British counterpart added that the demolition of the camp would "disrupt illegal immigration and people trafficking routes" and deter migrants from seeking to come to Britain (Garnham 2009). The discourses of barbarism and disorder thus set the context for enforced action, namely the demolition of the camp and the dispersal or detention of its occupants.

The spatial clearing of the jungle was seen as asserting order and law back on the transgressed land. The violence of the demolition with bulldozers was justified through the expectation of expiating the land from the lawlessness. In a "dawn raid" (Garnham 2009) "bulldozers encircle[d] the camp" and 500 armed police - "one for each remaining migrant in the shanty town" - moved in (Reporter 2009). First they cleared the occupants; 278 of whom were detained, half of whom were children and were separated from the adults and taken to special centres (Garnham 2009). Then the police "brought in bulldozers to raze the maze of makeshift tents ... workers with chainsaws cut down the trees and scrub bush that had supported the tents" (Express 2009). Thus the violent barbarism of jungle not only set the context for its demolition, but also served to justify the violent forcefulness of this. The camp, it was claimed, had become a "magnet for people from all over the world determined to cross the Channel and reach Britain" and the French minister claimed that is clearance was an 'important step in making Calais 'watertight' to illegal migrants" (Reporter 2009). The brutal clearing of the camps was also meant to be performative, exhibiting the decisive actions and firm stance taken by the authorities in dealing with these spatial transgressions, with both newspapers carrying images of the demolition. The clearing of the space and imaging of these was supposed to assuage the public as to how order had been restored and how the White spaces had been reclaimed from illegal migrants.

Despite the brutal demolition of the jungle and the declarations from both sides to secure Calais from illegal migrants, the phenomenon of the jungle could not be contained. New camps "popped up" in Calais hours after the Jungle was razed (Allen 2009b); "at least 20 new mini-camps" sprung up around the town over the next few weeks (Allen 2009d); and others sprouted "all along the northern French coast" (Sparks 2009b). These were "makeshift" shelters "strategically located" on main transit routes, but unlike the Jungle many were "well hidden from main roads" (Giannangeli 2009) or "secret homes" created after "forcing open the doorways" of the wartime blockhouses (Allen 2009b). Some of these new camps were torn down but the French authorities "admitted ... they are fighting a losing battle against migrants desperate to reach Britain" (Allen 2009e) and to stop new jungles springing up. The mayor of Calais claimed the "squalid conditions" in some of these shelters was "almost identical [to] ... the socalled Jungle" (Allen 2009b), feared the "danger" of mini-camps "mushrooming into a new 'Jungle" (Allen 2009b), and reported that there were frequent "outbreaks of violence," particularly knife fights between migrants and people traffickers (Sparks 2009b).

Within a year there were reports that a "New Jungle" had sprung up in the village of Teteghem, near Dunkirk (Finan and Allen 2010). Newspapers were less interested in the discourse of environmental squalor and more interested in the theme of encroachment, violence and threat. The village of 7500 residents had been "invaded" by 50 new migrants a week and "over-run" by a camp of 200(Finan and Allen 2010). The local mayor attributed the sprouting of the New Jungle to the "changed situation" following the demolition of its Calais predecessor, where migrants were now "trying" to get to Britain from "Dunkirk and the Belgian ports of Zeebrugge and Ostend" (Finan and Allen 2010). People traffickers had targeted Teteghem because of its strategic location near the port of Dunkirk, then charged migrants to camp in the village (Finan and Allen 2010). There were reports of recent stabbings and shootings and local residents felt threatened by "dangerous and very violent" people traffickers and by "hardened" migrants with "nothing to lose and [who] will stop at nothing to get what they need" (Finan and Allen 2010). This promoted authorities into renewed action and the police "swoop[ed] on 200 British-bound migrants," demolished the camp and dispersed its occupants again in 2010 (Reporter 2010).

The closing of Sangatte and the demolition of the Calais jungle had been seen by British and French politicians in instrumentalist terms, as a way to "stop migrants flooding into Calais" (Daily Mail 2009) but a year later "they 
continue to flood into the town" (Sparks 2010). Local aid workers dismissed the demolition of the camps as little more than a "publicity stunt" intended to "placate the British public" and that they "had no effect at all" (Sparks 2010). Unable to stop new migrants coming into the coastal areas, French politicians blamed their British counterparts for the "shambles" (Fagge 2009) and demanded that Britain sign up to the Schengen Agreement and allow free movement of migrants already within the EU (Allen 2009d). The mayor of Calais claimed that the "port would remain an immigrant dumping ground until Britain opened its borders and stopped asking France to do its dirty work," but this, the newspaper argued, would "allow all migrants to flood across the Channel” (Allen 2009d).

With the French authorities unable to stop new migrants moving into coastal areas and their failure to persuade Britain to open its borders, they were left to manage the spaces they occupied. Nevertheless, a clear conflict emerged between the political determination to take a tough stance and the determination of the courts to uphold human rights. These ruled that "collective arrests" after the demolition of the Calais jungle infringed individual rights (Reid 2009) and upheld the "migrants' right not to be detained" and their "fundamental freedom" to claim asylum where they chose, (Sparks 2010) effectively challenging EU policy.

\section{| Conclusion}

This article set out to explore how two mid-market British newspapers constructed a particular social imaginary of migrant spaces and camps through the spatial metaphor of the jungle. We contend that the meaning of these camps needs to be understood in a particular context of territorial politics of space on the French coastline, centred on migrant shelters, which fractured basic human needs, juxtaposing the need for shelter as illegitimate, against other basic needs as legitimate. It was in this context that the jungle metaphor came to ascribe particular meanings to migrant camps that extended beyond functional spaces of shelters and opportunities to incorporate the barbaric. These were spaces of the uncouth and unordered. The barbarism was captured in the accounts of the environmental degradation of spaces that evolved organically (or through orchestration by criminals) and that encroached on surrounding environs as well as of spaces of violent lawlessness. Both were seen as warranting violent demolition. However, this failed to end the barbarism but dispersed it along the coast in mini-camps that created a new meaning of the jungle as an open-ended space. It also entrenched a powerful social imaginary in which many migrants already deemed illegal under changes to EU asylum law on asylum were seen as sub-human through their occupation of spaces of barbarism.

\section{Endnotes}

1. A notion of the jungle as a barbaric space can also be found in Upton Sinclair's exploited meat-packers in The Jungle (1906) and Evan Hunter's account of uncontrolled, violent children in an inner-city school in the Blackboard Jungle (1955). However these do not draw on the colonial subject and most of the migrants in the newspaper articles were from the former colonies.

\section{References}

Aas, Katja, F. 2011. "Crimmingrant" bodies and bona fida travellers: Surveillance, citizenship and global governance. Theoretical Criminology, 15 (3), pp. 331-346. Accessed at http://tcr.sagepub.com/cgi/doi/10.1177/1362480610396643
Achebe, Chinua, 1977. An image of Africa: Racism in Conrad's "Heart of Darkness". Massachussetts Review. (18th edition) 
Allen, Peter, 2008. Mass riot police operation to break up Calais camps full of Brit-bound migrants. MailOnline. http:// www.dailymail.co.uk/news/article-1079955/Mass-riotpolice-operation-break-Calais-camps-Brit-bound-migrants. html\#ixzz2au2DfVfY

Allen, Peter, 2009a. Afghan man stabbed to death in fight between rival migrant gangs battling for passage to UK. MailOnline. Accessedhttp://www.dailymail.co.uk/news/article-1109402/ Afghan-man-stabbed-death-fight-rival-migrant-gangs-battlingpassage-UK.html\#ixzz2au8Tne2f.

Allen, Peter, 2009b. Pictured: New squalid migrant camp pops up in Calais hours after the Jungle is razed. MailOnline. Accessedhttp://www.dailymail.co.uk/news/article-1215568/ New-squalid-migrant-camp-pops-Calais-hours-Jungle-razed. html\#ixzz2avXFqLTX

Allen, Peter, 2009c. Riot squads seize "people smugglers" in swoop on port.Express. http://www.express.co.uk/news/uk/96326/ Riot-squads-seize-people-smugglers-in-swoop-on-port

Allen, Peter, 2009d. The UK must open its borders: Calais mayor's demand as riot police tear down illegal camps AGAIN. MailOnline. Accessed athttp://www.dailymail.co.uk/news/ article-1216950/Riot-police-destroy-Calais-migrant-campsAGAIN-mayor-slams-Britain-unable-control-borders. html\#ixzz2avbj8LGX

Anderson, Benedict, 1991. Imagined communities: reflections on the origins and spread of nationalism. London: Verso

Dominic, Thomas, 2013. African and France: Postcolonial cultures, migration and racism. Bloomington: Indiana University Press, pp. 169-188

Boswell, Christina, 2012. How information scarcity influences the policy agenda: Evidence from UK Immigration Policy. Governance. 25 (3) pp 367-389

Bosworth, Mary, 2012. Subjectivity and identity in detention: Punishment and society in a global age. Theoretical Criminology. 16 (2) pp 123-140

Bosworth, Mary and Guild, Mhairi, 2008. Governing through migration control: Security and citizenship in Britain. British Journal of Criminology. 48 (6) pp 703-719

Bracchi, Paul, 2009. Bloody siege of Calais: The violent new breed of migrants who will let nothing stop them coming to Britain. MailOnline.http://www.dailymail.co.uk/news/article1202009/Bloody-siege-Calais-The-violent-new-breed-migrantslet-stop-coming-Britain.html.

Davies, Nick, 2009. None deadlier than the Mail. New Statesman, p. 21

Doughty, Steve, 2012. France could quit EU open borders deal because of illegal migration, warns Sarkosy. MailOnline. Available at:http://www.dailymail.co.uk/news/article2113708/Nicolas-Sarkozy-France-quit-EU-open-borders-dealillegal-immigration.html

Dove, Michael, R. 1992. The dialectical history of the "jungle" in Pakistan: An examination of the relationship between nature and culture. Journal of Anthropological Research. 48 pp. 231-253.
Durkheim, Emile, 1915. The elementary forms of religious life. London: Allen and Unwin.

Express. 2009. Migrant "jungle" camp bulldozed. Accessed athttp://www.express.co.uk/news/world/129163/ Migrant-jungle-camp-bulldozed

Fagge, Nick, 2009. Now French blame us for their migrant camps crisis.Express. http://www.express.co.uk/news/uk/79243/ Now-French-blame-us-for-their-migrant-camps-crisis

Fernandes, Edna, 2009. Welcome to heaven, how about a cup of tea? Mail on Sunday special investigation into why asylum seekers lead to Britain. MailOnline.Accessed at: http://www. dailymail.co.uk/news/article-1227779/Welcome-heaven-cuptea-Mail-Sunday-special-investigation-asylum-seekers-headBritain. html ?printingPage $=$ true

Finan, Tim and Allen, Peter, 2010. Stop being so generous to migrants: French plea to Britain after Dunkirk suburb is over-run. MailOnline. Accessedhttp://www.dailymail.co.uk/ news/article-1331013/Stop-generous-migrants-French-pleaBritain-Dunkirk-suburb-run.html

Garnham, Emily, 2009. Police swoop on sprawling immigrant “jungle”.Express. Accessed at: http://www.express.co.uk/news/ uk/129166/Police-swoop-on-sprawling-immigrant-jungle

Geddes, Andrew, 2004. Getting the best of both worlds? Britain, the EU and migration policy. International Affairs. 81 (4) 723-740

Giannangeli, Marco, 2009. Dunkirk beaches shelter army of migrants.Express. Accessed http://www.express.co.uk/news/ world/130191/Dunkirk-beaches-shelter-army-of-migrants

Greenslade, Roy, 2004. Press gang: how newspapers make profits from propaganda. Basingstoke: Pan MacMillan.

Harvey, David, 1973. Social Justice and the City. London: Edward Arnold.

Harvey, David, (1990) Between Time and Space: Reflections on the Geographical Imagination. Annals of the Association of American Geographers, 80 (3) 418-434

Hickley, Matthew, 2009. Gallic snub for Woolas over immigrant camp as the French say they know nothing of Calais plan. MailOnline. Accessedhttp://www.dailymail.co.uk/news/ article-1162702/Gallic-snub-Woolas-immigrant-campFrench-say-know-Calais-plan.html

Horak, Jan-Christopher, 2006. Wildlife documentaries: From classical forms to reality TV. Film History: An International Journal, 18 (4) 459-475

Howarth, Anita and Ibrahim, Yasmin, 2012. Threat and Suffering: The Liminal Space of "The Jungle" in Les Andrews and Hazel Roberts (eds) Liminal Spaces. London: Routledge

Ibrahim, Yasmin, 2011. Constructing "The Jungle": Distance framing in the Daily Mail. International Journal of Media \& Cultural Politics. 7 (3) 21-34 
Ibrahim, Yasmin, 2012. Temporality, Space and Technology: Time-Space Discourses of Call Centres. New Technology, Work and Employment, 27(1) 23-35

Isin, Engin and Rygiel, Kim, 2007. Of Other Global Cities: Frontiers, Zones, Camps in Drieskens Barbara, Mermier Franck and Wimmen Heiko (eds). Cities of the South, London: Saqi 170-201.

Massey, David, 1991. The political place of locality studies. Environment and Planning, A. 23 267-281

May, Jon, 1996. Globalization and the politics of place: place and identity in an inner London neighbourhood. Transactions of the Institute of British Geographers, 21 (1) pp 194-215

McBratney, John, 1992. Imperial space in Kipling's "Jungle Book", Victorian Studies 35 (3) pp, 277-293

Moores, Shaun, 2004. The doubling of place, MediaSpace: Place, scale and culture in a media age, 21

Millner, Naomi, 2011. From "refugee" to "migrant" in Calais solidarity activism: Re-staging undocumented migration for a future politics of asylum. Political Geography, 30 pp 320-328

Mulvey, Geoff, 2010. When policy creates politics: The problematizing of immigration and the consequences for refugee integration in the UK. Journal of Refugee Studies, 23 (4) pp 437-462

Nyman, Jopi, 2001. Re-reading Rudyard Kipling's "English heroism": narrating nation in The Jungle Book. Orbis Litterarum, 53 (3) pp 205-220

Rawstorne, Tom, 2009. Hundreds of illegal immigrants armed with knives and crowbars swarm round Calais trucks heading for Britain. MailOnline.Accessed: http://www.dailymail.co.uk/ news/article-1180180/Hundreds-illegal-immigrants-armedknives-crowbars-swarm-round-Calais-trucks-heading-Britain. html ?printingPage $=$ true

Reid, Sue, 2009. They're back: Mass of migrants queue up at Sangatte to reach "Promised Land", UK. MailOnline, Accessedhttp://www.dailymail.co.uk/news/article-1161659/ Theyre-Mass-migrants-queue-Sangatte-reach-Promised-LandUK.html

Reporter, 2010. Calais: Riot police smash refugees' new Jungle. Express, Accessed http://www.express.co.uk/news/ world/213348/Calais-Riot-police-smash-refugees-new-Jungle
Reporter, 2009. Razed to the ground: Jungle migrant camp emptied after raid by Calais police (but will it stop asylum seekers flooding into Britain?).MailOnline. Accessed http:// www.dailymail.co.uk/news/article-1214848/Britain-obsessedasylum-seekers-let-UK-earliest-convenience-says-EuropesJustice-Commisioner.html?printingPage $=$ true

Reynolds, Mark, 2009. Migrants: Nothing will stop us getting in to the UK. Express. Accessed http://www.express.co.uk/news/ uk/129057/Migrants-Nothing-will-stop-us-getting-in-to-UK

Scannell, Paddy, 1989. Public service broadcasting and modern public life.Media Culture Society, 11 (2) pp 135-166

Shields, Rob, 1999. Culture and the economy of cities. European Urban and Regional Studies 6 (4) pp 303-311

Sparks, Ian, 2010. Bulldozing of Calais immigration camp was a "publicity stunt aimed at placating the British public". MailOnline. Accessed http://www.dailymail.co.uk/news/ article-1242854/Calais-Jungle-Bulldozing-immigrationcamp-publicity-stunt-aimed-placating-British-public. html? printingPage $=$ true

Sparks, Ian, 2009a. Calais opens "welcome centre" to help migrants stay in France ... and gets ZERO enquiries (proof they all want to come to Britain?) MailOnline, Accessed http://www.dailymail.co.uk/news/article-1178088/Guessmigrants-turned-Calais-stay-France-welcome-centre-Thatsright-NONE.html

Sparks, Ian, 2009b. French politician arrested for "smuggling 16 Vietnamese migrants into Britain". MailOnlne. Accessedhttp://www.dailymail.co.uk/news/article-1219039/ French-politician-arrested-smuggling-16-Vietnamesemigrants-Britain.html

Sparks, Ian, 2009c. Police swoop on people trafficking network accused of smuggling 5,000 illegal immigrants into Britain. MailOnline. Accessedhttp://www.dailymail.co.uk/news/ article-1192110/Police-swoop-people-trafficking-networkaccused-smuggled-5-000-illegal-immigrants-Britain.html

Tristem, Alan, 2007. The return of Sangatte, Express, p. 6

Trudeau, David, 2006. Politics of belonging in the construction of landscapes: place-making, boundary-drawing and exclusion. Cultural Geographies, 13 (3) pp 421-433

Wright, Christopher, 2006. Welcome to the Jungle of the Real: Simulation, Commoditization and Survivor. The Journal of American Culture, 29 pp 170-182 
